This item was submitted to Loughborough's Research Repository by the author.

Items in Figshare are protected by copyright, with all rights reserved, unless otherwise indicated.

\title{
Explaining the electoral performance of populist parties: the Netherlands as
}

\section{a case study}

\section{PLEASE CITE THE PUBLISHED VERSION}

http://dx.doi.org/10.1080/15705854.2011.546148

\section{PUBLISHER}

(c) Taylor \& Francis

\section{VERSION}

AM (Accepted Manuscript)

\section{PUBLISHER STATEMENT}

This work is made available according to the conditions of the Creative Commons Attribution-NonCommercialNoDerivatives 4.0 International (CC BY-NC-ND 4.0) licence. Full details of this licence are available at: https://creativecommons.org/licenses/by-nc-nd/4.0/

\section{LICENCE}

CC BY-NC-ND 4.0

\section{REPOSITORY RECORD}

Van Kessel, Stijn. 2019. "Explaining the Electoral Performance of Populist Parties: The Netherlands as a Case Study". figshare. https://hdl.handle.net/2134/16895. 


\section{Explaining the electoral performance of populist parties: the Netherlands as a case study.}

Stijn van Kessel

Final version in:

Perspectives on European Politics and Society, 12 (1), 2011, pp. 68-88.

\section{Introduction}

Throughout the last decades various European countries have witnessed an increase in the electoral support for populist parties. There has been substantial scholarly attention for the performance of these parties, mostly focusing on radical right-wing variants in Western Europe. The role of these parties themselves in shaping their electoral fortune has been somewhat understudied, however. This article does consider the populist parties' agency as one of the vital factors in explaining for the electoral performance of populist parties. Other crucial variables it indentifies are the availability of the electorate and the responsiveness of established parties. The importance of these explanatory conditions is illustrated by means of a study of populist parties in the Netherlands.

In the Netherlands, two populist parties have managed to obtain a considerable share of the vote in recent elections. After the rise of Pim Fortuyn in 2002 and the subsequent decline of his party, Dutch party politics has been rocked again by the Freedom Party of Geert Wilders. This party became the third largest party in Dutch parliament after the general election of June 2010. Yet, various other populist parties have made less successful attempts in general elections. The Netherlands thus lends itself as a case in which successful and unsuccessful manifestations of populism can be compared, providing an ideal 'laboratory' environment for learning about the electoral performance of populist parties in general. Thus, while the characteristics of the Dutch populist parties are in some ways unique, the findings of this contribution are likely to also have wider implications with regard to the electoral performance of populist parties in other countries. 
This article claims that a combination of explanatory conditions is crucial in understanding populist electoral fortune and hardship. Accordingly, this contribution will argue that the electoral success of the Dutch populist parties has been facilitated by the availability of the Dutch electorate, which became increasingly detached from traditional political parties. To understand the actual breakthrough of populist parties and their subsequent success or failure to survive, however, the agency of political actors must be considered. This relates, in the first place, to the responsiveness of established political parties. As will be shown, by the turn of the $21^{\text {st }}$ century neither of the mainstream parties sufficiently responded to the electorate's concerns related to immigration and cultural integration of, most notably, the Muslim minority population. This provided a favourable opportunity structure for the Dutch populist anti-establishment parties that focused on these issues. Secondly, as noted above, the credibility of the populist parties themselves has proven to be crucial to their breakthrough and electoral persistence. This relates to the skill of the populist party leadership and the ability to build up a sound party organisation after the initial breakthrough.

The following section touches on the concept of populism and the way populist parties are defined in this contribution. The subsequent section introduces the theoretical framework. Afterwards, the Dutch political background, the electoral developments and the characteristics of the most notable populist parties - the List Pim Fortuyn and the Freedom Party - are discussed. The remainder of the article focuses on explaining the electoral performance of populist parties in the Netherlands.

\section{Populist parties}

The concept of 'populism' is ambiguous due to the fact that it is often ill-defined and used in a haphazard fashion (see Taggart \& Van Kessel, 2009; Van Kessel et al., 2008). Although it goes beyond the scope of this contribution to do the conceptual debate justice, it is necessary to provide a definition of populism in order to clarify the selection of populist cases in this article. Political parties are here classified as populist parties if they (1) delineate an exclusive community of 'ordinary people', (2) appeal to these 
'ordinary' people, whose interests and opinions should be central in making political decisions, (3) are fundamentally hostile towards the (political) establishment, which allegedly does not act in the interest of the ordinary people (see e.g. Canovan, 1981; Taggart, 2000; Mudde, 2004; Albertazzi \& McDonnell, 2008).

Populist parties thus position the 'ordinary people' and 'the establishment' in an antagonistic relationship. It is obviously not self-evident who belongs to these 'ordinary people' and populists are often not very specific about their core target audience. Instead, this community of 'ordinary people', the populist 'heartland' in the words of Paul Taggart (2000), is often rhetorically constructed in a negative manner. Populists normally identify those people that do not belong to the community (see Mudde, 2007; Albertazzi \& McDonnell, 2008). Immigrants and minority groups are usual suspects, although populists are not necessarily xenophobic. The group of 'others' could, for instance, also consist of corporate elites, the media or intelligentsia whose ideas, values and interests are at odds with those of the ordinary people.

Populists are in any case opposed to the political powers that be. Residing in their ivory towers, the members of the political establishment lost track of the everyday problems of the people. The critique of populist parties goes further than condemning a particular political party or government - all (opposition) parties do that from time to time. Populists criticise the whole established political system and those parties that are seen to be part of it. A new way of decision-making is required, one that is straightforward, transparent and effectively copes with the people's problems.

A final note is that populist parties do not necessarily intend to get their following directly involved in politics. Instead, the populist party or, more specifically, the populist leader claims to speak in the name of the people; the populist knows what the ordinary people want and truly represents their interests.

On the basis of this definition, the populist parties in the Netherlands will be identified. This article particularly focuses on the List Pim Fortuyn and Geert Wilders' Freedom Party, the populist parties that made most of an impact. In the analysis dealing with the electoral performance of populist parties, however, also the less successful 
populists will be discussed. The next section firstly outlines the theoretical framework for this analysis.

\section{Explaining the electoral performance of populist parties}

The central question in this contribution is how the electoral performance of populist parties can be explained. Various studies have tried to account for the performance of non-mainstream 'challenger' parties, especially extreme/radical right or anti-immigrant parties (e.g. Kitschelt \& McGann, 1995; Lubbers et al., 2002; Carter, 2005; Van der Brug et al., 2005; Norris, 2005). Several other accounts deal with the performance of populist parties (Albertazzi \& McDonnell, 2008) and populist radical-right parties in particular (Betz, 1994; Rydgren, 2004; Mudde, 2007; Bornschier, 2010) Amir Abedi (2004) broadened the scope by studying the performance of 'Anti-Political Establishment' parties more generally. These studies regularly focus on structural factors, like economic conditions, the electoral system and other institutional rules, but do not always yield similar results (see e.g. Jackman \& Volpert, 1996; Carter, 2005; Arzheimer \& Carter, 2006). Also the ideological placement of mainstream parties and their rivals and the convergence of mainstream parties have been taken into consideration in order to account for new non-mainstream party performance.

This study cannot truly take institutional factors into account, as it focuses on a single country. Besides, in view of the varying performance of populist parties in the Netherlands throughout the years, the marked proportionality of the Dutch electoral system is certainly not a sufficient condition for populist electoral success. Also economic conditions, as will be shown below, did not account for the breakthrough of populist parties at the beginning of the $21^{\text {st }}$ century. Finally, instead of measuring party distances in a one- or multi-dimensional ideological space, this article focuses on the responsiveness of established parties with regard to specific societal issues. Determining party positions or assessing the distance between parties mainly relates to the political supply-side. This study starts off from the notion that the responsiveness of established 
parties to the voters' demands - relating to both demand- and supply-side - plays a more crucial role in explaining populist electoral performance.

A more structural factor to be considered firstly, however, is the availability of the electorate (see Bartolini \& Mair, 1990; Bartolini, 1999). This relates to the voters' ties with established parties; is the electorate marked by strong partisan commitments or are many voters 'available' to be swayed by newly established parties? Abedi (2010) indeed finds that weak party partisan attachment is conducive to the success of anti-political establishment parties.

The two other factors this study distinguishes are related to the agency of political parties. Firstly, as mentioned, the responsiveness of established political parties is likely to play a significant role (Hauss \& Rayside, 1978: 38). If established parties do not recognise the salience of particular issues within society or if they fail to represent a dominant position with regard to those, they are potentially vulnerable to the rise of new challengers. Especially populist parties, which fundamentally criticise the political establishment, are likely to thrive when established political parties are perceived to be unresponsive to the demands of the 'ordinary citizens'. Apart from more substantive policy-related motivations, a vote for a populist party typically is an expression of dissatisfaction with the political establishment (see Bélanger \& Aarts, 2006). Existing parties, however, may hamper the development of populist parties by successfully seizing the ownership of the issues addressed by the populists (see Bale, 2003; Meguid, 2008).

Finally, even if the breeding ground for populism is present, there would be no populist success without the supply of a credible populist political party. The importance of party organisation and leadership for explaining new (populist) party success has been acknowledged (e.g. Betz 1998: 9; Albertazzi \& McDonnell 2008). As Cas Mudde (2007: 275) notes with regard to the populist radical right, only few theoretical frameworks, however, take into account the agency of these parties themselves. In her comparative analysis dealing with Western European extreme right parties Elisabeth Carter (2005) does consider these parties' agency. She finds that especially the strength of the party 
organisation and the skill of the party leadership are important in terms of these parties' electoral performance (see also Lubbers et al., 2002). This is very likely to apply to populist parties as well; populist parties have to present themselves as viable alternatives to the established parties in order to become successful. Particularly with regard to populist parties, the appearance of the party leader plays a crucial role. Populist parties tend to be hierarchical organisations, spearheaded by a dominant and strong leader.

Measuring the credibility of populist parties is not an easy task, however. A qualitative assessment seems the best way to proceed when dealing with this variable. Another challenge is not to fall in a tautology trap; it is easy enough to ascertain that successful populist parties must have presented themselves as credible challengers. Therefore, it is necessary to look at indictors of credibility before the elections actually took place.

In terms of party leadership skills, this account assesses whether the populist parties have managed to attract sufficient media attention and whether the party (leader) made a strong impression during the election campaign. Also the credibility of the populist anti-establishment message is considered. It can be difficult for populist parties to convincingly stick to their anti-establishment appeal once they take place in government, as they have to become part of the system they previously vehemently opposed (Taggart, 2000).

In line with Mudde's (2007: 275-6) assertion, leadership seems particularly important with regard to the breakthrough of populist parties, whereas the electoral persistence of the parties relies very much on their party organisation. After their breakthrough, populist parties are likely to lose their credibility if they fail to preserve internal discipline and cohesion (Norris 2005: 263). As mentioned above, since populist parties are generally leader-centred organisations, they are especially likely to fall apart when the leader departs or loses grip on the party. The lack of a developed grass-root organisation, supplying fitting and reliable personnel for political office, is also conducive to internal instability. 
This article thus identifies three factors which are deemed crucial to explain the electoral performance of populist parties: availability of the electorate, responsiveness of the established parties and the availability of credible populist parties. Arguably, similar variables can be identified to study the electoral performance of new 'challenger' parties more generally. This account, however, focuses on the elements relevant to populist parties in particular, such as the leader-centeredness and the populist anti-establishment appeal.

Finally, it is worth mentioning that the causal conditions outlined above are not entirely unrelated. A lack of established parties' responsiveness, for instance, may increase the availability of an electorate which has become disillusioned with its political elite. For analytical purposes, however, it makes sense to separate the variables. Moreover, whereas many scholars focus on individual variables in explaining the electoral success of (populist) political parties, this paper argues that it is the combination of explanatory conditions that is crucial in understanding populist electoral fortune. Independence of the variables outlined here is thus not so much a vital matter.

\section{Populist parties in the Netherlands ${ }^{1}$}

During the $20^{\text {th }}$ century populist parties have sporadically appeared in the Dutch party system, although they never became successful for an extended period of time. The Farmer's Party (Boerenpartij) broke through in the 1960s, but would never receive more than $4.8 \%$ of the vote. Also the ethno-nationalist xenophobic parties led by Hans Janmaat in the 1980s and 1990s (the Centre Party and Centre Democrats), could only count on limited and short-lived electoral success. Another populist party that emerged was the left-wing Socialist Party (SP). In the 1990s the party with Maoist roots could be described as a 'social-populist' party (March \& Mudde, 2005). However, in more recent years the party got, to a considerable degree, rid of its populist rhetoric and turned into a more conventional social-democratic party (De Lange \& Rooduijn, 2011; Voerman \& Lucardie, 2007). This process had started before the general election of 2002, when the party grew and collected just under $6 \%$ of the vote, and was more or less completed 
when the SP reached its high point in 2006 with over $16 \%$ of the vote. The party's real breakthrough was thus not so much driven by its populism.

It was only after the turn of the $21^{\text {st }}$ century that a whole array of populist parties appeared on the Dutch political scene. Therefore, although the credibility of the SP and Janmaat's parties will be discussed later, this contribution predominantly focuses on the electoral performances of populist parties since the rise of Pim Fortuyn.

\section{The rise and fall of the List Pim Fortuyn}

The recent electoral success of Geert Wilders' Freedom Party (Partij voor de Vrijheid, PVV) can hardly be seen independent from the previous rise of another populist politician in 2002: Pim Fortuyn. Fortuyn mainly reacted against the two 'Purple' coalition governments that had been formed in 1994 and 1998. These coalitions consisted of the 'red' Labour Party (Partij van de Arbeid, PvdA), the 'blue' Liberals (Volkspartij voor Vrijheid en Democratie, VVD) and the smaller progressive Liberal D66 (Democraten 66). During this period, the Christian Democrats, since 1980s united in the Christian Democratic Appeal (Christen Democratisch Appel, CDA), were excluded from government for the first time since 1918.

Fortuyn, a columnist and former sociology professor, founded his party List Pim Fortuyn (Lijst Pim Fortuyn, LPF) after he was expelled from the also newly formed party 'Liveable Netherlands' (Leefbaar Nederland, LN). After his dismissal Fortuyn could immediately count on a substantial amount of support in the pre-election polls. According to the criteria outlined above, the List Pim Fortuyn was a populist party. Fortuyn appealed to the 'ordinary people', although he did not always explicitly describe his projected following as such. Still, his populist appeal can be noted in his book annex political programme 'The shambles of eight years Purple': "The Netherlands should become a real lively democracy of and for the ordinary people, and depart from the elite party democracy we are currently acquainted with" (Fortuyn, 2002, pp. 186). What is more, according to Fortuyn, power would have to be returned to the 'people in the country' (Lucardie, 2008); the number of managers and bureaucrats had to be reduced 
and responsibility would have to be returned to the 'real' experts: the nurses, teachers and police officers (LPF, 2002). Besides, as is clear from the examples above, Fortuyn expressed harsh critique on the political establishment, the incumbent 'Purple' government in particular. In the official election manifesto it is argued that 'Purple' has left the Netherlands with a rigid and self-satisfied political culture of appointed executives lacking creative or learning capacities (LPF, 2002, pp. 1).

Apart from the party's populist features, the LPF's more substantive political programme was rather eclectic (Lucardie, 2008); Fortuyn generally promoted a freemarket economy, tough measures with regard to law and order issues and stressed the need to cut red tape in the healthcare and education sectors. At the same time, however, his position on moral or cultural issues like drugs and traditional marriage was very liberal.

Yet it was in his stance on immigration and integration that Fortuyn attracted most controversy. According to the LPF manifesto, crowdedness in The Netherlands caused growing societal tensions and it was therefore necessary to resist immigration of more, often unemployed and unskilled, foreigners into the country (LPF, 2002, pp. 5). The programme also speaks of problems caused by the social-cultural backwardness of large groups in society and related problems like criminality and discrimination of women, especially in fundamentalist Islamic circles. Fortuyn sought to protect the Dutch liberal way of life against foreign cultural influences that clashed with the Dutch or, more broadly, Western liberal Enlightenment values (Akkerman, 2005). His ideology was at odds with the idea of a diverse multicultural society in which liberal principles came under pressure.

Fortuyn would not witness the results of the general elections; on May 6 he was murdered by an environmental activist. The campaign was officially cancelled, but the elections were not, and despite the dramatic incident the remaining List Pim Fortuyn members decided to participate. On the $15^{\text {th }}$ of May the LPF won $17.0 \%$ of the vote and 26 of the 150 seats in the Dutch parliament (see table 1). This was an unprecedented result for a new party; the former 'record' for a newcomer being 8 seats for DS'70 in 
1971. At the same time, the Purple coalition partners suffered an enormous defeat. The LPF would join a coalition government with the Christian Democrats and the Liberals. However, it proved to be the shortest incumbent government in Dutch history; after 87 days the coalition partners CDA and VVD brought it down after a period of severe LPF infighting.

A new general election was scheduled for January 2003. Under the leadership of former Fortuyn spokesman Mat Herben, the LPF lost most its previous support, gaining $5.7 \%$ of the vote and 8 seats. On first sight the results of the 2003 general elections seemed to indicate a return to 'old' politics; the established parties recovered quite well from their electoral blow in 2002. Also, no new parties managed to enter parliament.

$* * *$ TABLE 1 HERE $* * *$

\section{The rise of Geert Wilders}

The subsequent general election of 2006 saw the return of a populist party. The Freedom Party of Geert Wilders received $5.9 \%$ of the vote and nine seats. Wilders was a former MP for the Liberal Party (VVD) who broke with his party in September 2004 after a conflict with the parliamentary leader over the issue of Turkish EU membership. Wilders refused to give up his seat in Parliament and formed his own one-man fraction 'Group Wilders', or Freedom Party as he later named it.

In terms of populism, Wilders appeals to the 'ordinary people' even more explicitly and criticises the established political elite more harshly than Fortuyn used to do. Wilders (2005, pp. 1) speaks of a "range of interlinked crises which flow from the incompetence of the political elite in Brussels and The Hague". In his 'declaration of independence' Wilders (2005, pp. 2) further states: "I do not want this country to be hijacked by an elite of cowardly and frightened people (from whichever party) any longer. (...) Therefore, I intend to challenge this elite on all fronts. I want to return this country to its citizens". Wilders despises the self-sustaining political system which stands isolated from society; "politicians should no longer be deaf to the problems troubling 
ordinary people in every-day life" (Wilders, 2005, pp. 16).

In terms of substantive policies, Wilders' initial appeal was similar to Fortuyn's, but more radical as regards immigration and integration. Islam is perceived as a violent 'ideology' and Dutch culture should be protected against the process of 'Islamisation' (Vossen 2010). The manifesto of 2010 nevertheless argues that the PVV is not a oneissue party, as Islamisation touches on a range of other social issues: "Economically it is a disaster, it damages the quality of our education, it increases insecurity on the streets, causes an exodus out of our cities, drives out Jewish and gay people, and flushes the century-long emancipation of women down the toilet" (PVV, 2010, pp. 6).

Finally, although Wilders predominantly agitates against the 'left-wing' elites and their expensive 'left-wing hobbies' like foreign aid and art, the social-economic programme of the PVV in 2010 was eclectic and included various left-wing measures. Wilders had always been against raising the pension age, but before generally favoured a small state and a flexible labour market (Wilders, 2005; PVV, 2006). In 2010, however, the PVV called for the preservation of the welfare state and was against easing the rules for laying off employees, amending unemployment benefits and more marketisation in the health care sector. Nevertheless, the PVV was at the same time against abolishing the mortgage interest relief and in favour of tax cuts and deregulation for business entrepreneurs.

The general election results of June 2010 showed that Geert Wilders had managed to extend his support base significantly. With $15.5 \%$ of the vote and 24 seats Wilders came close to the amount of support the List Fortuyn gathered in 2002. The Freedom Party became the third largest party in parliament. Another ex-Liberal politician voicing populist rhetoric, Rita Verdonk with her movement 'Proud of the Netherlands' (Trots op Nederland, TON), failed to cross the electoral threshold.

Wilders eventually signed an agreement to support the minority coalition between the Liberals and the Christian Democrats. This Cabinet was officially installed in October 2010. Although the Netherlands has a long tradition of majority governments, the election outcome thus resulted in a construction similar to the Danish case. Here, the 
populist anti-immigrant People's Party has supported minority coalitions since 2001.

How can the electoral performances of the List Pim Fortuyn and the Freedom Party, as well as the less successful populist parties, be explained? The remainder of this paper will deal with this question, setting off from the theoretical framework outlined earlier.

\section{Explaining the rise (and fall) of populist parties in contemporary Dutch politics}

\section{The availability of the electorate}

The first condition conducive to the recent breakthrough of populist parties in the Netherlands relates to the availability of the electorate, which has changed considerably throughout the past decades. The electorate was relatively unavailable in the decades after the Second World War due to the 'pillarised' structure of Dutch society. This meant that the major Dutch parties and the most significant religious and social groups, or 'pillars', were closely aligned (Lijphart, 1975). Thus, the electorate largely voted along the cleavage lines of religion and social class, being represented by either the Christian Democratic Parties, the Labour Party, representing the working class, or the Liberal Party, representing the secular middle class (e.g. Van Holsteyn \& Irwin, 2003; Andeweg \& Irwin, 2002).

$* * *$ TABLE 2 HERE $* * *$

The dividing lines between pillars gradually evaporated, however, largely due to the secularisation of society since the 1960s. People's sociological background still predicted voting behaviour quite well in the following decades, especially with regard to the religious pillars (see table 2) (Van Holsteyn \& Irwin, 2003). By the turn of the $21^{\text {st }}$ century, however, the explanatory power of this factor had become very low. As table 2 shows, the 'structural model' based on these traditional cleavages explained $72 \%$ of the 
total vote in 1956 . This percentage gradually declined and in 2002 only $28 \%$ of the vote could still be explained by this model. Hence, due to the declining partisan alignments the availability of the voters in the Netherlands gradually increased and, at present, voters' sociological background hardly predicts voting behaviour anymore. In other words, "the closed political and electoral system opened up, the 'pillars' of Dutch society began to crumble, and voters finally began to choose" (Van Holsteyn \& Irwin, 2003, pp. 48).

The increased availability of the electorate becomes apparent if one looks at the aggregate levels of electoral volatility; the voteshare that shifts from one party to another between elections. If ties between parties and their traditional support bases have weakened one would expect voters to switch between parties to a greater extent. Indeed, as figure 1 shows, electoral volatility in the Netherlands has taken a vast flight from the elections in 1989 onwards. The most recent volatility figures are even the highest in Western Europe (Mair, 2008).

\section{$* * *$ FIGURE 1 HERE $* * *$}

The increased availability of the Dutch electorate had serious consequences for the fortunes of small and newly formed parties. These previously used to remain marginal in terms of size and influence, if they managed to enter the Dutch parliament at all (Krouwel \& Lucardie, 2008; Van Kessel \& Krouwel, 2011). These consequences were particularly serious in view of the highly proportional Dutch electoral system which has, in theory, always been very open to new political parties (Mair, 2008).

In order to account for the electoral performance of populist parties, however, also the agency of political parties has to be considered.

\section{Responsiveness of the established parties}

Before the rise of Fortuyn, some scholars already predicted the potential for populist parties in The Netherlands. Rudy Andeweg (2001, pp. 123), for instance, argued that the 
Dutch consensus democracy would provide fertile grounds for critique from the populist right, as consensus democracies are "strong on inclusiveness and weak on accountability". Also Jacques Thomassen (2000) predicted that there was potential for the populist radical right, although he related it more specifically to the convergence of the mainstream parties towards the political centre.

The findings of Pennings and Keman (2003), based on data from the Comparative Manifestos Project, indeed confirm that the mainstream parties in the Netherlands have converged. The authors also see this as one of the main factors behind Fortuyn's success. The public was not able to distinguish between mainstream parties anymore, and Fortuyn was able to occupy the political space that has become vacant.

Figure 2 depicts the traditional mainstream parties' position on the specific issue of multiculturalism - one of the issues Fortuyn attracted most attention with - since 1981. The figure indicates whether the parties, on balance, made more positive or negative comments about multiculturalism, including matters such as cultural integration and preservation of cultural and religious heritage (see Budge et al., 2001; Klingemann et al., 2006). The graph shows that in the 1980s the three parties did not perceive multiculturalism as a negative phenomenon. In the 1990 s only the Liberals were critical of multiculturalism. During these years, Liberal leader Bolkestein indeed voiced concern that a lack of integration of minority groups would threaten (secular) Western liberal achievements (Prins, 2002).

\section{$* * *$ FIGURE 2 HERE ***}

By 2002, however, the Liberals had stopped pressing the issue of multiculturalism and little was separating the three mainstream parties on this issue. This gave Fortuyn the room to position himself as the main critic of multicultural society. In 2003, according to the data, the Labour Party and the Liberals had shifted their positions towards multiculturalism dramatically (see also Oosterwaal \& Torenvlied, 2010). Interestingly, however, neither of these parties have succeeded in (re)gaining full 
'ownership' of this issue, in view of the more recent electoral success of Geert Wilders' Freedom Party.

Be that as it may, the fact that the mainstream parties did not press certain issues or the fact that party programmes have converged throughout time does not necessarily mean that parties have also been unresponsive. Perhaps the issue of multiculturalism was not perceived to be very important by the Dutch electorate. This, however, was certainly not the case. As Pellikaan, De Lange and Van der Meer (2003; 2007) argue, the established parties failed to recognise that citizens actually were concerned about the perceived problems of immigration and the 'multicultural' character of society. Fortuyn managed to introduce a new 'cultural' line of political conflict which "had been ignored by the political elite, but was highly salient to the electorate" (Pellikaan et al., 2007, pp. 294).

On the basis of Dutch Parliamentary Election studies Kees Aarts and Jacques Thomassen (2008, pp. 217) indeed find that since the early 1990s the electorate saw problems related to minorities and refugees very important societal issues. As figure 3 indicates, these issues suddenly became more important for many voters at the turn of the 1990s, while, most notably, unemployment became much less of a salient issue. Also in view of the good economic record of the Purple government, the success of Fortuyn was thus not so much related to socio-economic conditions (Van Holsteyn \& Irwin, 2003).

$* * *$ FIGURE 3 HERE $* * *$

As Aarts and Thomassen argue, none of the established political parties prioritised these newly emerged issues in their political programme in 2002. Furthermore, the perceived positions of the Christian Democrats and especially the Labour Party towards ethnic minorities and asylum seekers were quite different from the attitudes of the electorate. Similarly, Van Holsteyn, Irwin and Den Ridder (2003) argue that it was not so much the electorate that shifted to the 'right' at the 2002 general elections; the public 
merely reacted to the entrance of a credible newcomer which tapped into their preexisting attitudes.

The rise of Pim Fortuyn can thus be seen as the result of the perception among a considerable share of the electorate that the mainstream political parties did not sufficiently take into account salient social issues. A vote for Fortuyn was not merely a protest vote driven by political apathy or cynicism (Van der Brug, 2003), even though attitudes of discontent are also likely to have contributed to the support of Fortuyn (Bélanger \& Aarts, 2006). Judging from figure 4, LPF voters indeed seemed driven by the substance of Fortuyn's programme, but the LPF vote was also largely propelled by dissatisfaction with the Purple government or a feeling that Dutch politics needed to be shaken up.

$* * *$ FIGURE 4 HERE $* * *$

Even if the mainstream parties adapted their positions after the elections of 2002, they do not seem to have regained the confidence of a considerable share of the dissatisfied electorate. The lack of confidence in politicians particularly shows when the opinions of Freedom Party voters are considered. According to data from the Dutch Parliamentary Election Study from 2006, roughly two-thirds of Wilders' electorate agreed with the statement that 'MPs do not care about opinions of people like me', whereas about one-third of the non-Freedom Party voters agreed with this (see figure 5).

*** FIGURE 5 HERE $* * *$

In attempting to reap from this public dissatisfaction Wilders seemed to have made a sensible choice in writing a more left-wing manifesto in terms of socio-economic issues. As Van der Brug and Van Spanje (2009) have argued, in Western Europe there is a substantial group of people who are left-leaning on socio-economic policies and rightleaning on immigration. Like in most other countries, in the Netherlands there was no 
party truly representing this group of voters in recent years. It seemed thus logical for Wilders to include various more left-leaning proposals in his 2010 programme as, for, instance the Danish People's Party has done before. Indeed, a post-election survey of research institute Synovate (2010) suggests that the Freedom Party managed to win over many former, presumably 'left-wing', Labour and Socialist Party supporters. Also many former Liberal, Christian Democrat and non-voters cast their ballot on Wilders in 2010, however, indicating that Wilders truly had become a 'catch-all populist'.

Yet, if the breeding ground for populism has been present all along, how can the failure of other populist parties and the electorate's return to the established parties in 2003 be explained? To account for this, the agency of the populist parties themselves has to be considered.

\section{Supply of credible populist parties}

Even if the breeding ground for populism has been present in the Netherlands, there would have been no populist success without the supply of a credible populist political party; a party marked by skilful leadership and a decent party organisation (Carter, 2005). Pim Fortuyn's popularity, and the success of populist leaders in general, is often related to personal 'charisma' (e.g. Ellemers, 2004). However, this 'charisma hypothesis', based on the notion that a vote for a populist party is largely motivated by the extraordinary endowments of the populist leader alone, has been rightly criticised (Van der Brug, 2003; Van der Brug \& Mughan, 2007). Indeed, as has been shown above, people voting for populist parties seem to be motivated by substantive concerns, just like supporters of any other parties.

This is not to say that party leaders, especially of populist parties, do not play an important role. On the basis of the 2006 Dutch Parliamentary Election Study, Van Holsteyn and Andeweg (2008) show that a mere $8 \%$ of all respondents answered that they would follow the leader of the party they preferred if he or she would switch to another party. With regard to supporters of the Freedom Party, a party so clearly centred around Wilders, this figure was $25 \%$. Furthermore, in the election campaign of 2002 the 
importance of the leadership factor was evident; the support for 'Liveable Netherlands' in the polls only truly began to rise under Pim Fortuyn's leadership. After the forced departure of Fortuyn in February 2002 it became even clearer that it was the appeal of Fortuyn that really mattered; most Liveable supporters followed him to his new party.

In the pre-Fortuyn era populist parties could not rely on such an extraordinary figurehead. The populist anti-immigrant Centre Party and Centre Democrats, led by the late Hans Janmaat, only had some very limited success in the 1980s and 1990s. Between 1994 and 1998 the Centre Democrats reached their peak with 3 seats, before disappearing from parliament in 1998. Janmaat was hardly an appealing leader. Whilst being a confident speaker, he was "not really eloquent and often too emotional to convince anyone but his own supporters" (Lucardie, 1998: 116). Besides, in terms of organisation, both Janmaat's parties were not free from internal disputes. Janmaat was actually expelled from the Centre Party in 1984 and founded the Centre Democrats afterwards. Finally, as figure 3 has shown, immigration only really became a salient issue in the 1990s. During most of this decade Liberal leader Bolkestein managed to effectively voice discontent as regards the, allegedly too liberal, Dutch migration policy (Lucardie, 1998: 122). This is likely to have reduced the appeal of the Centre Democrats even further.

The Socialist Party, in turn, lacked sufficient nationwide visibility until the late 1990s (Van der Steen, 1995; Voerman \& Lucardie, 2007). After the disappointing 1989 general election the party broadened the scope of its campaign efforts and the party became known for its telling campaign slogan 'Vote against, vote SP!' (Stem tegen, stem SP!). The Labour party, meanwhile, received criticism for the cuts in social benefits during its time in office. In 1994 the SP managed to win two seats and grew further in 1998, receiving five seats. Jan Marijnissen grew out to be an appealing, eloquent leader and the party remained well organised.

However, in order to appeal to a wider audience the party let go of its more radical policies and dropped references to its communist heritage (Voerman \& Lucardie, 2007). Moreover, as discussed previously, also its populist rhetoric waned. In 2002 the 
party's slogan, for instance, had remarkably changed in 'Vote for, vote SP' (Stem voor, stem SP!). The party now presented itself as a more leftist alternative to Labour, rather than a pure populist anti-establishment party. This also shows in the motivations of its electorate. According to Dutch Parliamentary Election Study data only $2.6 \%$ of the Socialist Party voting respondents gave 'to shake up the Netherlands, change or dissatisfaction with the Purple Cabinet' as a reason as to why they voted for the party in 2002 (Irwin et al., 2003). This compares to a figure of no less than $31.5 \%$ for LPF voting respondents (see figure 4).

Compared to the SP, Pim Fortuyn clearly needed less time to put his party in the spotlights. He dominated the campaign of 2002 and was also by far the most visible politician in the media (Kleinnijenhuis et al, 2003). With his effective performance he placed the established parties in a difficult position. The most notable occasion where this happened was the TV debate following the municipal elections in March. The broadcast showed the grumpy looking Labour and Liberal party leaders being unable, and seemingly unwilling, to respond to the triumphant monologues of Pim Fortuyn.

Fortuyn's dominance in the campaign does not necessarily say something about his popularity. Koopmans and Muis (2009) do find, however, that the public visibility of Fortuyn combined with the support from other actors in the public sphere proved to be beneficial for Fortuyn's support in the pre-electoral opinion polls. Van Holsteyn and Irwin (2003) further show that although Fortuyn was clearly perceived as the least sympathetic party leader on the whole, a large share of the voters that did evaluate Fortuyn favourably also cast a vote for him. Whereas Fortuyn and his ideas were thus highly controversial, he was nevertheless seen as the right candidate by a substantial part of the electorate.

Once represented in parliament and government, however, Fortuyn's party failed to leave a good impression. This related, above all, to the organisational weakness of the party after Fortuyn's assassination. Directly after Fortuyn had been murdered, the internal turmoil began and the struggles continued after the List Pim Fortuyn became part of the governing coalition. It was without doubt the continuous infighting between 
LPF cabinet members - most notably the ministers Heinsbroek and Bomhoff - MPs and party officials that caused the breakdown of the government. Without Pim Fortuyn, the party organisation of the LPF proved to be no more than loose sand. In the words of former party leader Mat Herben: "Not one organisation is able to function without (accepted) leadership, loyalty and discipline. After Pim Fortuyn had gone there was a lack of all three within the LPF" (Herben, 2005, pp. 25).

The results of the 2003 general elections seemed to indicate a return to 'old' politics. The fact that the LPF, despite the enormous organisational chaos, still managed gather $5.7 \%$ of the vote showed that a substantial amount of voters was reluctant to return to the mainstream parties, however. Besides, no other serious populist contender with similar ideas to Fortuyn participated in the 2003 general elections. Liveable Netherlands was torn by leadership struggles; it was strikingly the inexperienced and unknown younger sister of former Fortuyn spin-doctor Kay van der Linde who eventually became the party leader. The person who missed out on LN leadership, the well known 'motivation trainer' Emile Ratelband, competed with his own list, but seemed too much of a controversial and, different to Fortuyn, incapable candidate ${ }^{2}$. Neither Liveable, nor Ratelband received enough votes to become represented in parliament. With her new party Winny de Jong, former List Pim Fortuyn MP, also stood for the elections, but she lacked media attention, and she was too much associated with the LPF skirmishes to secure seats.

In 2006 the situation was different; several right-wing populist candidates emerged with a certain political track record. Former List Pim Fortuyn immigration minister Hilbrand Nawijn formed the Party for the Netherlands (PVN) and Marco Pastors, former alderman for Fortuyn's local party Liveable Rotterdam, and Joost Eerdmans, who had been a prominent List Pim Fortuyn MP, formed One NL (EénNL). Finally, List 5 Fortuyn more or less emerged out of the original LPF, although its leader Olaf Stuger was by far the most unknown party leader of the newly emerged populist parties and the party's campaign appeared to be quite poor $^{3}$. It was Geert Wilders, however, who managed to collect most of the populist votes. 
Having learned from the mistakes of the List Pim Fortuyn, Wilders managed to keep the ranks within the party closed after the election. Wilders was very clear about wanting to avoid 'LPF-like situations' when deciding to only stand in two municipalities in the local election in March 2010, due to the lack of qualified candidates. At the same time, his popularity grew steadily and he received ample media attention with strong statements and, in particular, with his controversial anti-Islam film Fitna from 2008 (Vossen, 2010). Even though immigration and Islam was not the prime issue of the election campaign of 2010 , Wilders still managed to make a strong appearance in TV debates and to present himself as the saviour of the economic interests of ordinary hard working men and women (Van Kessel, 2010). A first crack in the party organisation appeared to materialise when Freedom Party MP Hero Brinkman openly dissented with the opinion of Wilders related to terms of government participation. Wilders, however, reacted calmly in his public appearance the next day and effectively managed to hush the rumour.

The other right-wing populist who stood in the 2010 general election, Rita Verdonk, was a much less powerful contender. Although polls indicated that she could rely on a substantial amount of support just after the launch of her movement Proud of the Netherlands (Vossen 2010), Verdonk struggled to retain media attention in the following years. Also during the 2010 campaign she hardly played a visible role. Unlike Wilders, she was not invited to the debates involving the supposed main contenders of the election. Also in organisational terms, Verdonk failed to leave a good impression. In 2008 she had to break with two of her closest trustees: Kay Verlinden - after his negative remarks about the party leaked out - and Ed Sinke - after a vicious personal conflict.

The Freedom party of Geert Wilders, in contrast, agreed to support a minority government. This situation appears to be very advantageous for him. Through the support agreement he is able to influence government policy, but he can still blame the government - in which his party is not officially taking part - for taking less popular measures. In this way, Wilders might be able to continue to voice a credible anti- 
establishment message.

Whether Wilders is able to keep his party organised, however, is a different question. As early as November 2010, the Dutch media widely reported about the missteps various Freedom Party MPs have made in the past. The most prominent scandal involved MP Eric Lucassen who, apart from allegedly howling unwelcome remarks at neighbours, was convicted during his time in the army for engaging in sexual activities with lower-ranked personnel. Despite this, Lucassen remained seated in parliament for the Freedom Party. At the time of writing, there are no signs of these affairs having a negative effect on the popularity of Geert Wilders' party. If incidents like these will continue in the future, however, it remains to be seen whether Wilders can fend off 'LPFlike situations'.

\section{Conclusions and implications}

This contribution has sought to outline key causal conditions related to the electoral performance of populist parties, using the Netherlands as a case study. The case of the Netherlands can be seen as an ideal 'laboratory' case in view of the varying levels of success for Dutch populist parties in recent years. This article argued that the combination of three causal conditions has been crucial: the availability of the electorate, the responsiveness of established parties and the supply of credible populist parties.

As has been shown, the structures of party competition in the Netherlands have become highly favourable to the electoral success of populist parties. The electorate has become increasingly available after the demise of the pillarised cleavage structures, which meant that, in more recent years, new parties were fully able to profit from the highly proportional Dutch electoral system.

In addition, the agency of political parties played a crucial role. Political mainstream parties were widely perceived to be unresponsive to the demands of a substantial part of the electorate. The most important issues at stake were immigration and cultural integration of minorities. Whereas the party of Pim Fortuyn failed to sustain, his populist critique was not silenced and the potential for new populist entrepreneurs 
remained very much present. In 2006 another populist party entered the Dutch Parliament: the Freedom Party of Geert Wilders. This party became the third largest party in Dutch Parliament after the general election of 2010 and provides support for the minority government that was subsequently formed.

Finally, whereas the credibility of the List Pim Fortuyn was damaged due to continuous infighting and while other populist contenders lacked appeal, Geert Wilders managed to build up a united party organisation under his own firm leadership while sending out an appealing message to a large share of the Dutch voters. Whether he will manage to preserve cohesion and credibility in the future remains to be seen, however.

The Dutch case suggests that mainstream parties do not automatically win back the support they lost to the populists if they become more responsive. In the Netherlands, immigration and cultural integration are now important issues to most political parties, but this does not seem to hamper Geert Wilders' success. This suggests that if a populist party manages to retain its credibility, it can ward off competition from its mainstream rivals.

What is more, as the Freedom Party is not officially part of the government it remains to be seen whether a 'black-widow effect' will materialise (Bale 2003). This happens when mainstream parties gobble up the electoral support of the radical junior coalition partner by copying its policies. The Freedom Party can, instead, claim credit for tougher immigration and integration measures, whilst blaming the government for less electorally appealing policies. The Danish People's party, which has incrementally extended its support during the past decade, serves as a good example.

Further research is required to assess the plausibility of the arguments outlined here. One of the main points this contribution has attempted to stress, in any case, is the importance of populist party agency. This factor should also be taken into account in comparative and quantitative studies on the electoral performance of such parties.

\section{Note}




\footnotetext{
${ }^{1}$ All quotes from interviews, party documents and other literature in this section and beyond are translated from Dutch into English by the author.

${ }^{2}$ Ratelband, who had become a famous TV personality, did not have any political experience. His motivational training methods included loudly exclaiming the catchword 'Tsjakka' and convincing people to walk over hot coals barefoot.

${ }^{3}$ In order to show how close List 5 Fortuyn allegedly was to the original ideas of Pim Fortuyn, the party's campaign video showed a man - face concealed yet smartly dressed like Fortuyn - being parachuted from the skies, landing in the midst of the Dutch parliamentary buildings. The man turns out not to be Fortuyn, but Olaf Stuger.
}

\section{Bibliography}

Aarts, K. \& J. Thomassen (2008) Dutch Voters and the Changing Party Space 19892006, Acta Politica, 43(2-3), pp. 203-234.

Abedi, A. (2004) Anti-Political Establishment Parties. A comparative analysis (Oxon: Routledge).

Akkerman, T. (2005) Anti-immigration parties and the defence of liberal values: The exceptional case of the List Pim Fortuyn, Journal of Political Ideologies, 10(3), pp. 337-354.

Albertazzi, D. \& D. McDonnell (2008) Twenty-First Century Populism. The Spectre of Western European Democracy (Basingstoke: Palgrave MacMillan).

Andeweg, R. (2001) Lijphart versus Lijphart: the cons of consensus democracy in homogeneous societies, Acta Politica, 36, pp. 117-128.

Andeweg, R. \& G. Irwin (2002) Governance and Politics of the Netherlands (Houndmills: Palgrave MacMillan).

Arzheimer, K. and E. Carter (2006) Political opportunity structures and right-wing extremist party success, European Journal of Political research, 45(3), pp. 419443.

Bale, T. (2003) Cinderella and Her Ugly Sisters: The Mainstream and Extreme Right in Europe's Bipolarising Party Systems, West European Politics, 26(3), pp. 67-90.

Bartolini, S. (1999) Collusion, Comptetition and Democracy. Part I, Journal of Theoretical Politics, 11(4), pp. 435-470.

Bartolini, S. \& P. Mair (1990) Identity, Competition and Electoral Availability (Cambridge: Cambridge University Press).

Bélanger, É. \& K. Aarts (2006) Explaining the Rise of the LPF: Issues, Discontent, and the 2002 Dutch Election, Acta Politica, 41(1), pp. 4-20.

Betz, H.-G. (1994) Radical Right-Wing Populism in Western Europe (New York: St. Martin's Press). 
Betz, H.G. (1998) Introduction, in: H.-G. Betz \& S. Immerfall (Eds.) The New Politics of the Right. Neo-Populist Parties and Movements in Established Democracies, pp. 110 (New York, St. Martin's Press).

Bornschier, S. (2010) Cleavage Politics and the Populist Right. The New Cultural Conflict in Western Europe (Philadelphia: Temple University Press).

Budge, I., H.-D. Klingemann, A. Volkens, J. Bara \& E. Tanenbaum (2001) Mapping Policy Preferences. Estimates for Parties, Electors, and Governments 1945-1998 (Oxford: Oxford University Press).

Canovan, M. (1981) Populism (New York and London: Harcourt Brace Jovanovich).

Carter, E. (2005) The extreme right in Western Europe (Manchester: Manchester University Press).

CBS, SKON, H. van der Kolk, K. Aarts. M. Rosema \& M. Brinkman (2007) Dutch Parliamentary Election Study 2006 (The Hague: CBS/SKON).

De Lange, S. \& M. Rooduijn (2011, Forthcoming) Een populistische Zeitgeist in Nederland? Een inhoudsanalyse van de verkiezingsprogramma's van populistische en gevestigde politieke partijen. Contribution for the Democratic Audit of the Netherlands project.

Ellemers, J. (2004) Het fenomeen Fortuyn. De revolte verklaard, in: G. Voerman (Ed.) Jaarboek DNPP 2002, pp. 252-266 (Groningen: Rijksuniversiteit Groningen).

Fortuyn, P. (2002) De Puinhopen van acht jaar paars. Een genadeloze analyse van de collectieve sector en aanbevelingen voor een krachtig herstelprogramma. (Uithoorn-Rotterdam: Karakter Uitgevers-Speakers Academy).

Hauss, C. \& D. Rayside (1978) The development of new parties in western democracies since 1945, in: L. Maisel and J. Cooper (Eds.) Political Parties: Development and Decay, pp. 32-58 (London: Sage).

Herben, M. (2005) Vrij Denken: over religie, politiek en vrijmetselarij (The Hague: Synthese).

Irwin, G., J. van Holsteyn \& J.den Ridder (2003) Dutch Parliamentary Election Study 2002-2003 (Amsterdam: Rozenberg Publishers/NIWI-Steinmetz Archive/SKON).

Jackman, R. and K. Volpert (1996) Conditions Favouring Parties of the Extreme Right in Western Europe, British Journal of Political Science, 26(4), pp. 501-521.

Kitschelt, H. \& A. McGann (1995) The radical right in Western Europe: A comparative analysis (Ann Arbor: University of Michigan Press).

Kleinnijenhuis, J., D. Oegema, J. de Ridder, A. van Hoof \& R. Vliegenthart (2003) De puinhopen in het nieuws: de rol van de media bij de Tweede Kamer verkiezingen van 2002 (Alphen aan den Rijn: Kluwer).

Klingemann, H.-D., A. Volkens, J. Bara, I. Budge \& M. MacDonald (2006) Mapping Policy Preferences II. Estimates for Parties, Electors, and Governments in Eastern Europe, the European Union and the OECD, 1990-2003 (Oxford: Oxford University Press).

Koopmans, R. \& J. Muis (2009) The rise of right-wing populist Pim Fortuyn in the Netherlands: A discursive opportunity approach, European Journal of Political Research, 48(5), pp. 642-664. 
Krouwel, A. \& P. Lucardie (2008) Waiting in the Wings: New Parties in the Netherlands, Acta Politica, 43(2-3), pp. 278-307.

Lijphart, A. (1975) The Politics of Accomodation: Pluralism and Democracy in the Netherlands, $2^{\text {nd }}$ edition (Berkeley: University of California Press).

LPF (2002) Lijst Pim Fortuyn. Zakelijk met een hart. General Election manifesto Lijst Pim Fortuyn, 2002.

Lubbers, M., M. Gijsberts \& P. Scheepers (2002) Extreme right-wing voting in Western Europe, European Journal of Political research, 41(3), pp. 345-378.

Lucardie, P. (1998) The Netherlands: The Extremist Center Parties, in: H.-G. Betz \& S. Immerfall (Eds.) The New Politics of the Right. Neo-Populist Parties and Movements in Established Democracies, pp. 111-124 (New York, St. Martin's Press).

Lucardie, P. (2008) The Netherlands: Populism versus Pillarization, in: D. Albertazzi \& D. McDonnell (Eds.) Twenty-First Century Populism. The Spectre of Western European Democracy, pp. 151-165 (Basingstoke: Palgrave MacMillan).

Mair, P. (2008) Electoral Volatility and the Dutch Party System: A Comparative Perspective, Acta Politica, 43(2-3), pp. 235-253.

March, L. \& C. Mudde (2005) What's Left of the Radical Left? The European Radical Left After 1989: Decline and Mutation, Comparative European politics, 3(1), pp. 2349.

Meguid, B. (2005) Competition Between Unequals: The Role of Mainstream Party Strategy in Niche Party Success, American Political Science Review, 99(3), pp. 347-359.

Mudde, C. (2004) The Populist Zeitgeist, Government and Opposition, 39(4), pp. 542-63.

Mudde, C. (2007) Populist Radical Right Parties in Europe (Cambridge: Cambridge University Press).

Norris, P. (2005) Radical Right. Voters and Parties in the Electoral Market (Cambridge: Cambridge University Press).

Oosterwaal, A. \& R. Torenvlied (2010) Politics Divided from Society? Three Explanations for Trends in Societal and Political Polarisation in the Netherlands, West European Politics, 33(2), pp. 258-279.

Pellikaan, H., T. van der Meer \& S. de Lange (2003) The Road from a Depoliticized to a Centrifugal Democracy, Acta Politica, 38(1), pp. 23-49.

Pellikaan, H., T. van der Meer \& S. de Lange (2007) Fortuyn's Legacy: Party System Change in the Netherlands, Comparative European Politics, 5(3), pp. 282-302.

Pennings, P. \& H. Keman (2003) The Dutch Parliamentary Elections in 2002 and 2003: The Rise and Decline of the Fortuyn Movement, Acta Politica, 38(1), pp. 51-68.

Prins, B. (2002) The Nerve to Break Taboos: New Realism in the Dutch Discourse on Multiculturalism, Journal of International Migration and Integration, 3(3/4), pp. 363-380.

PVV (2006) Verkiezingspamflet. General Election Manifesto Partij voor de Vrijheid, 2006.

PVV (2010) Partij voor de Vrijheid: De agenda van hoop en optimisme. Een tijd om te kiezen. General Election manifesto Partij voor de Vrijheid, 2010.

Rydgren, J. (2004) Explaining the Emergence of Radical Right-Wing Populist Parties: The 
Case of Denmark, West European Politics, 27(3), pp. 474-502.

Synovate (2010) Winst- en verliesrekening. Available at http://www.politiekebarometer.nl/pdf/winst\%20en\%20verlies.pdf (accessed: 23 June 2010).

Taggart, P. (2000) Populism (Buckingham and Philadelphia: Open University Press).

Taggart, P. \& S. van Kessel (2009, May) The Problems of Populism. Paper presented at the Dutch-Flemish conference 'Het Politicologenetmaal', Berg en Dal, The Netherlands.

Thomassen, J. (2000) Politieke veranderingen en het functioneren van de parlementaire democratie in Nederland, in: J. Thomassen, K. Aarts \& H. van der Kolk (Eds.) Politieke veranderingen in Nederland 1971-1998. Kiezers en de smalle marges van de politiek, pp. 203-218 (The Hague: SDU).

Van der Brug, W. (2003) 'How the LPF Fuelled Discontent: Empirical tests of explanations of LPF support, Acta Politica, 38(1), pp. 89-106.

Van der Brug, W., M. Fennema \& J. Tillie (2005) Why Some Anti-Immigrant Parties Fail and Others Succeed: A Two-Step Model of Aggregate Electoral Support, Comparative Political Studies, 38, pp. 537-573.

Van der Brug, W. \& A. Mughan (2007) Charisma, Leader effects and support for rightwing populist parties, Party Politics, 13(1), pp. 29-51.

Van der Brug, W. \& J. van Spanje (2009) Immigration, Europe and the 'new' cultural dimension, European Journal of Political Research, 48(3), pp. 309-334.

Van der Steen, P. (1995) De doorbraak van de 'gewone mensen'-partij. De SP en de Tweede-Kamerverkiezingen van 1994, in: Jaarboek DNPP 1994, pp. 172-189 (Groningen: DNPP).

Van Holsteyn, J. \& R. Andeweg (2008) Niemand is groter dan de partij: Over de personalisering van de Nederlandse electorale politiek, in: Jaarboek DNPP 2006, pp. 105-134 (Groningen: DNPP).

Van Holsteyn, J. \& G. Irwin (2003) Never a Dull Moment: Pim Fortuyn and the Dutch Parliamentary Election of 2002, West European Politics, 26(2), pp. 41-66.

Van Holsteyn, J., G. Irwin \& J. den Ridder (2003) In the Eye of the Beholder: The Perception of the List Pim Fortuyn and the Parliamentary Elections of 2002, Acta Politica, 38(1), pp. 69-87.

Van Kessel, S. (2010) 'The Dutch General Election of June 2010', European Parties Elections and Referendums Network, Election Briefing Paper no. 54.

Van Kessel, S., T. Bale \& P. Taggart (2008, May) Thrown around with abandon? Popular understandings of populism as conveyed by the print media: a UK case study. Paper presented at the Populism and Civil Society Conference, Florence, Italy.

Van Kessel, S. \& A. Krouwel (2011, forthcoming) Van vergankelijke radicale dissidenten tot kwelgeesten van de gevestigde orde: Nieuwe politieke partijen in Nederland en hun betekenis voor de representative democratie. Contribution for the Democratic Audit of the Netherlands project.

Voerman, G. \& P. Lucardie (2007) De Sociaal-Democratisering van de SP, in: F. Becker \& R. Cuperus (Eds.) Verloren Slag. De PvdA en de verkiezingen van november 2006, pp. 139-164 (Amsterdam: Mets \& Schilt/Wiardi Beckman Stichting). 
Vossen, K. (2010) Populism in the Netherlands after Fortuyn: Rita Verdonk and Geert Wilders Compared, Perspectives on European Politics and Society, 11(1), pp. 2238.

Wilders, G. (2005) Groep Wilders. Onafhankelijkheidsverklaring, Party Document Groep Wilders, The Hague.

Table 1: Dutch general election results 1998-2010.

\begin{tabular}{|l|c|c|c|c|c|}
\hline Party & $\mathbf{1 9 9 8}$ & $\mathbf{2 0 0 2}$ & $\mathbf{2 0 0 3}$ & $\mathbf{2 0 0 6}$ & $\mathbf{2 0 1 0}$ \\
\hline Labour Party (PVdA) & $29.0 \%(45)$ & $15.1 \%(23)$ & $27.3 \%(42)$ & $21.2 \%(33)$ & $19.6 \%(30)$ \\
\hline Liberals (VVD) & $24.7 \%(38)$ & $15.4 \%(24)$ & $17.9 \%(28)$ & $14.6 \%(22)$ & $20.4 \%(31)$ \\
\hline Chr. Democrats (CDA) & $18.4 \%(29)$ & $27.9 \%(43)$ & $28.6 \%(44)$ & $26.5 \%(41)$ & $13.7 \%(21)$ \\
\hline Democrats '66 (D66) & $9.0 \%(14)$ & $5.1 \%(7)$ & $4.1 \%(6)$ & $2.0 \%(3)$ & $6.9 \%(10)$ \\
\hline GreenLeft (GL) & $7.3 \%(11)$ & $7.0 \%(10)$ & $5.1 \%(8)$ & $4.6 \%(7)$ & $6.6 \%(10)$ \\
\hline Socialist Party (SP) & $3.5 \%(5)$ & $5.9 \%(9)$ & $6.3 \%(9)$ & $16.6 \%(25)$ & $9.9 \%(15)$ \\
\hline Christian Union (CU) & $3.2 \%(5)$ & $2.5 \%(4)$ & $2.1 \%(3)$ & $4.0 \%(6)$ & $3.3 \%(5)$ \\
\hline List Pim Fortuyn (LPF) & & $17.0 \%(26)$ & $5.7 \%(8)$ & $0.2 \%(0)$ & \\
\hline Liveable NL (LN) & & $1.6 \%(2)$ & & & \\
\hline Freedom Party (PVV) & & & & $5.9 \%(9)$ & $15.5 \%(24)$ \\
\hline Others & $4.9 \%(3)$ & $2.5 \%(2)$ & $2.9 \%(2)$ & $4.4 \%(4)$ & $4.1 \%(4)$ \\
\hline Total & $100 \%(150)$ & $100 \%(150)$ & $100 \%(150)$ & $100 \%(150)$ & $100 \%(150)$ \\
\hline
\end{tabular}

Note: Number between brackets represents number of seats. The percentage for the Christian Union (CU) in 1998 is the combined percentage of the GPV and RPF, the parties that later merged into the CU. Data from: http://www.parties-and-elections.de/netherlands.htm/

Table 2: Electoral choice according to social background 1956-2002 in percentages.

\begin{tabular}{|l|c|c|c|c|c|c|}
\cline { 2 - 7 } \multicolumn{1}{c|}{} & $\mathbf{5 6}$ & $\mathbf{6 8}$ & $\mathbf{7 7}$ & $\mathbf{8 6}$ & $\mathbf{9 8}$ & $\mathbf{0 2}$ \\
\hline Practising Catholic voting KVP/CDA & 95 & 72 & 66 & 66 & 53 & 66 \\
\hline Practising Dutch Reformed voting ARP, CHU/CDA & 63 & 55 & 52 & 58 & 44 & 53 \\
\hline Practising Calvinist voting ARP, CHU/CDA & 93 & 78 & 75 & 58 & 44 & 43 \\
\hline Secular working class voting Labour Party (PVdA) & 68 & 65 & 67 & 60 & 51 & 34 \\
\hline Secular middle class voting Liberal Party (VVD) & 32 & 25 & 30 & 28 & 31 & 19 \\
\hline $\begin{array}{l}\text { Total percentage of voters explained with } \\
\text { the structured model of electoral behaviour }\end{array}$ & $\mathbf{7 2}$ & $\mathbf{6 0}$ & $\mathbf{5 4}$ & $\mathbf{4 4}$ & $\mathbf{3 8}$ & $\mathbf{2 8}$ \\
\hline
\end{tabular}

Source: Van Holsteyn and Irwin (2003: 50). 
Figure 1: Aggregate Electoral volatility in the Netherlands

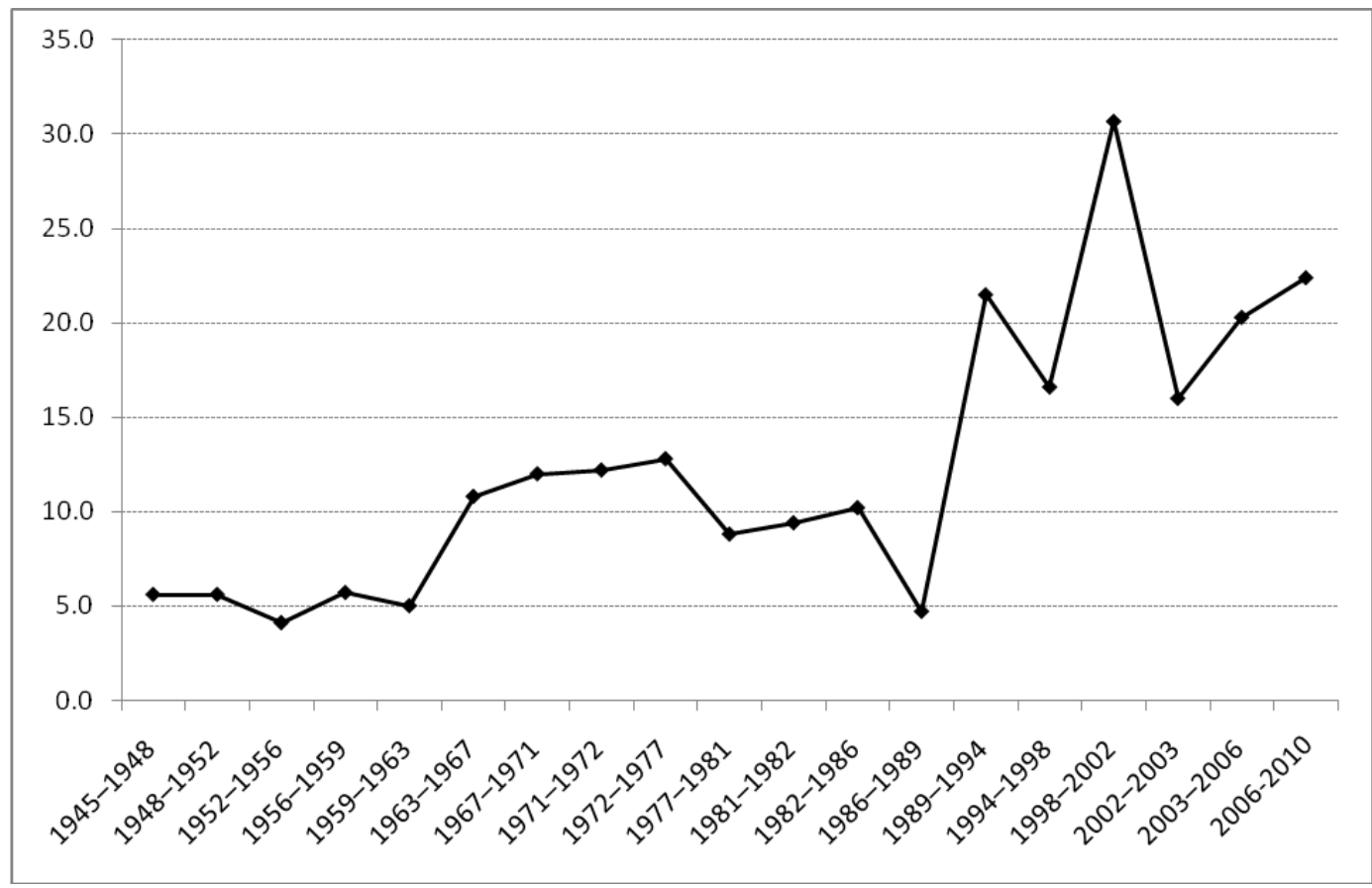

Source: Mair (2008). Figure for 2006-2010 based on own calculations.

Figure 2: Balance between positive and negative references regarding multiculturalism. 


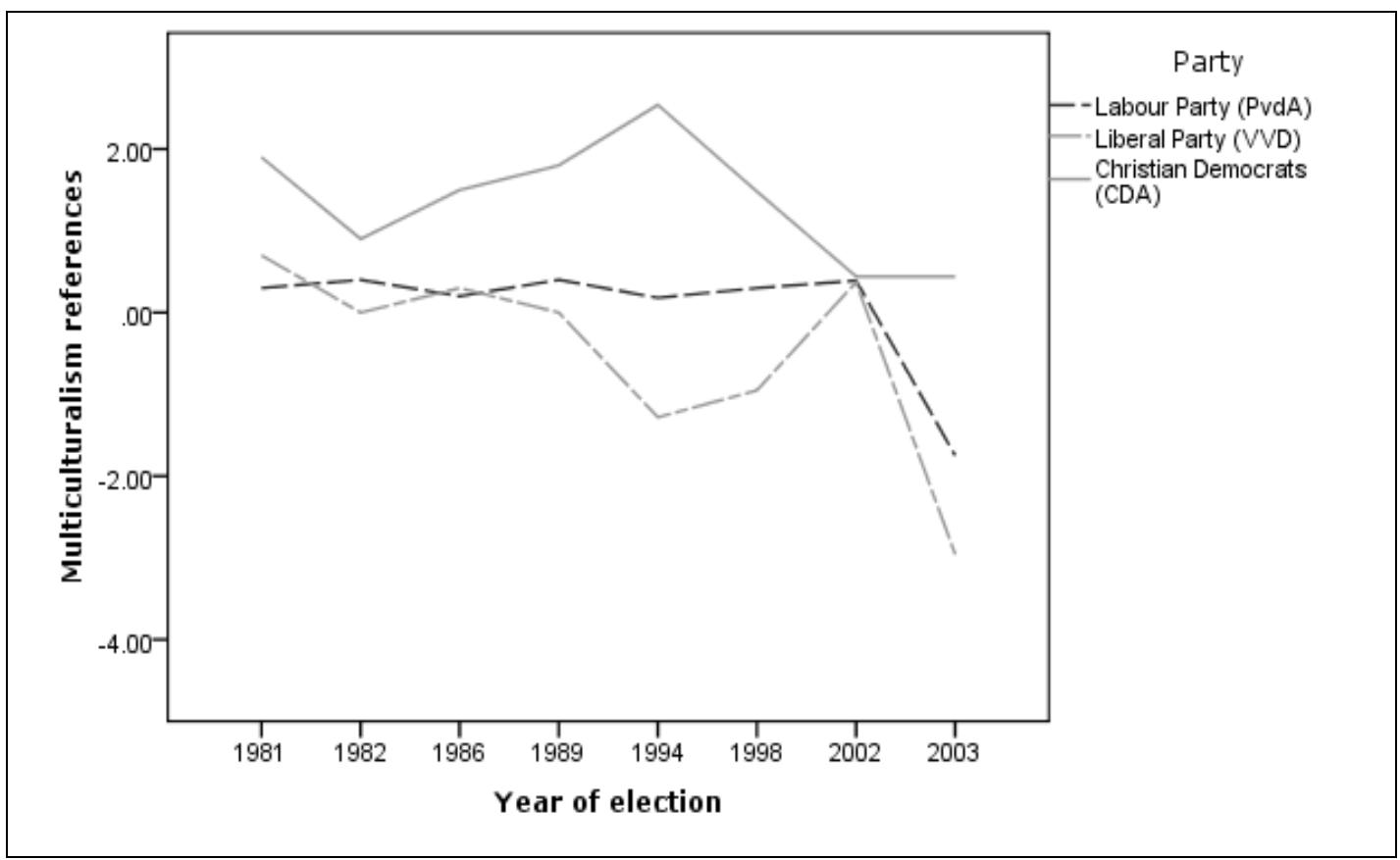

Data: Budge et al (2001), Klingemann et al (2006). The multiculturalism references scale is computed as: multiculturalism (positive references) minus multiculturalism (negative references).

Figure 3: Most important issues as perceived by the Dutch electorate

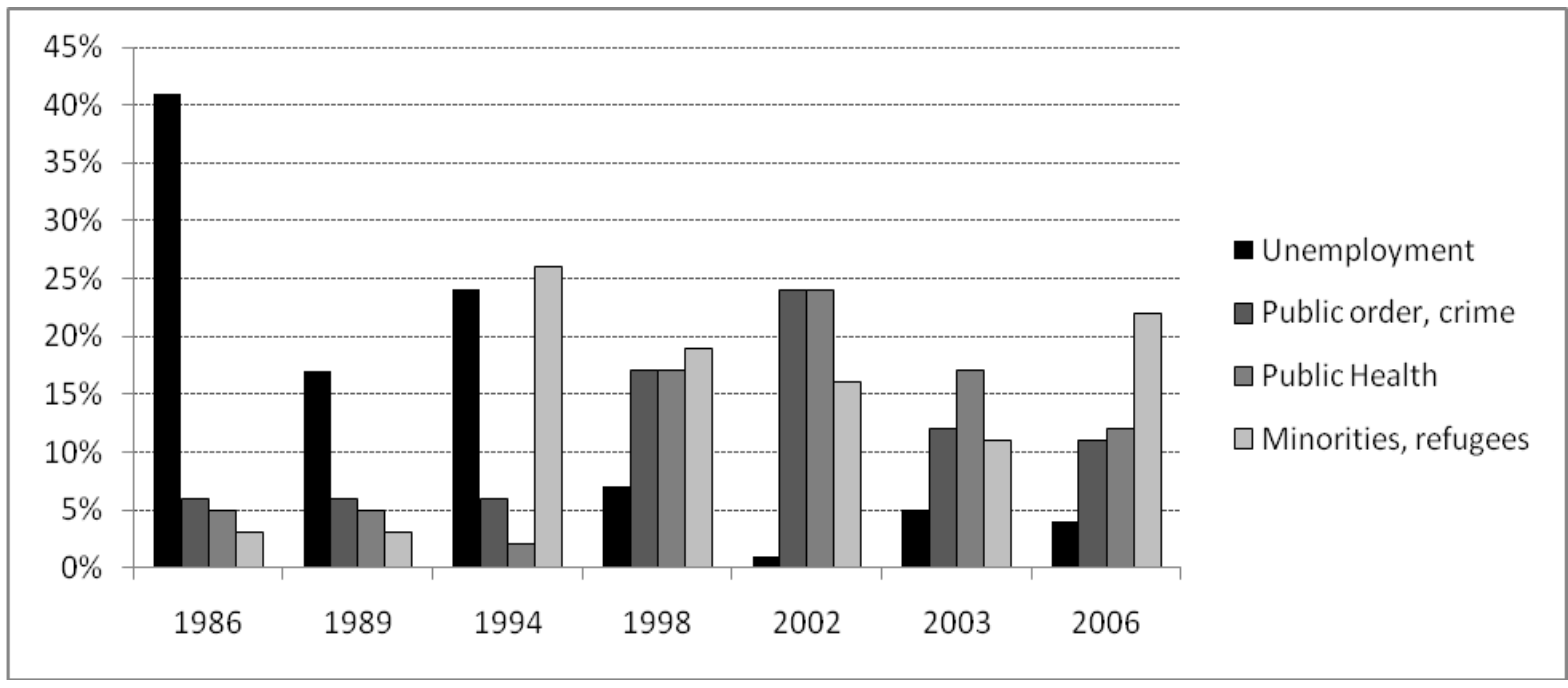

Source: Aarts and Thomassen (2008: 216).

Figure 4: Reasons behind party choice in general elections of 2002 


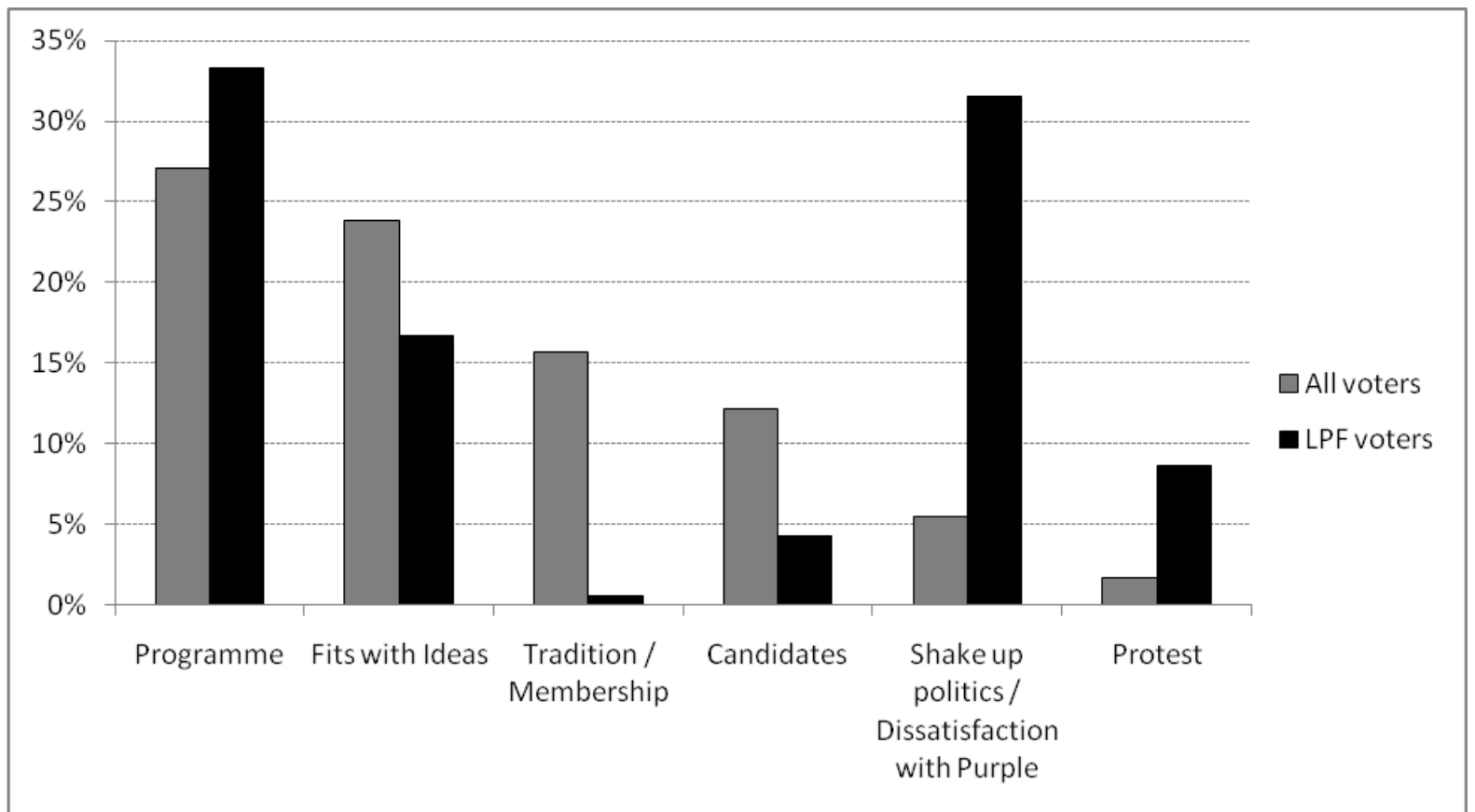

Data: Dutch Parliamentary Election Study 2002-2003 (Irwin et al 2003).

Figure 5: Views with the statement: 'MPs do not care about opinions of people like me'

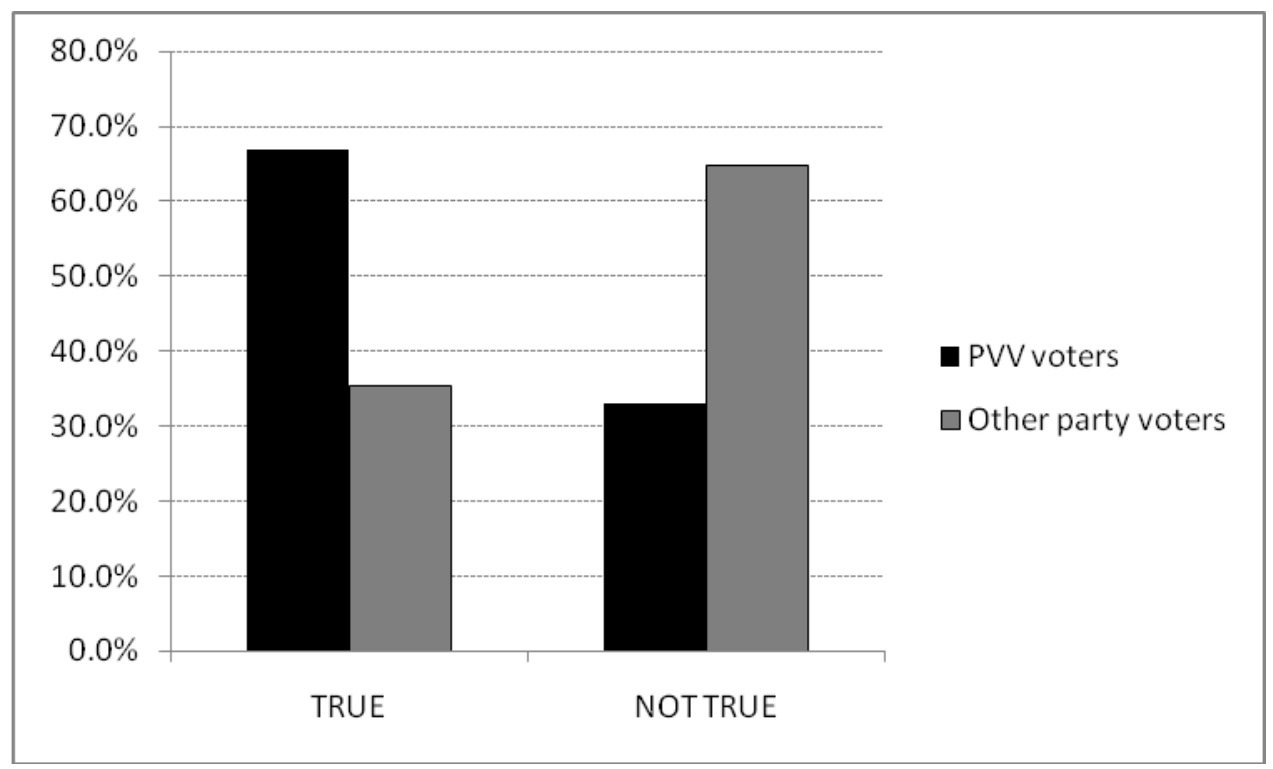

Data: Dutch Parliamentary Election Study 2006 (CBS et al 2007). 